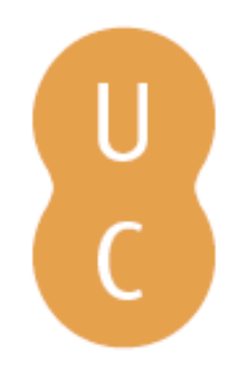

\title{
pompalina
}

\section{Between Epigram and Elegy: Horace as an Amatory Poet}

Autor(es): Konstan, David

Publicado por: Centro de Estudos Clássicos e Humanísticos; Imprensa da Universidade

URL

persistente: URI:http://hdl.handle.net/10316.2/32046

DOI: $\quad$ DOI:http://dx.doi.org/10.14195/978-989-8281-11-1_4

Accessed : $\quad$ 26-Apr-2023 15:29:37

A navegação consulta e descarregamento dos títulos inseridos nas Bibliotecas Digitais UC Digitalis, UC Pombalina e UC Impactum, pressupõem a aceitação plena e sem reservas dos Termos e Condições de Uso destas Bibliotecas Digitais, disponíveis em https://digitalis.uc.pt/pt-pt/termos.

Conforme exposto nos referidos Termos e Condições de Uso, o descarregamento de títulos de acesso restrito requer uma licença válida de autorização devendo o utilizador aceder ao(s) documento(s) a partir de um endereço de IP da instituição detentora da supramencionada licença.

Ao utilizador é apenas permitido o descarregamento para uso pessoal, pelo que o emprego do(s) título(s) descarregado(s) para outro fim, designadamente comercial, carece de autorização do respetivo autor ou editor da obra.

Na medida em que todas as obras da UC Digitalis se encontram protegidas pelo Código do Direito de Autor e Direitos Conexos e demais legislação aplicável, toda a cópia, parcial ou total, deste documento, nos casos em que é legalmente admitida, deverá conter ou fazer-se acompanhar por este aviso.

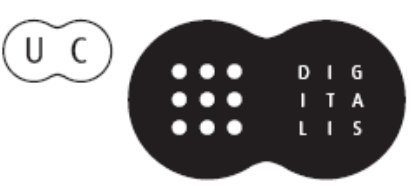




\section{Horácio \\ e a sua \\ Perenidade}

\section{Maria Helena Rocha Pereira, José Ribeiro Ferreira e Francisco de Oliveira}

IMPRENSA DA UNIVERSIDADE DE COIMBRA 


\title{
Between Epigram and Elegy: Horace as an Amatory Poet ${ }^{\text {I }}$
}

\author{
David Konstan \\ Brown University
}

When Horace published the first three books of his Odes, very probably in the year 23 B.C., when he was 42 years of age, a rather younger Propertius - perhaps 20 years Horace's junior - had recently brought forth the first book, or Monobiblos, of his elegies (dated to 25 B.C.), with two more books to follow in the subsequent two years (at least on a widely accepted dating). The fourth book of Horace's Odes was published a decade later than the first three, in 13 B.C., when Horace was now in his fifties; so too, the fourth book of Propertius' elegies appeared some time after 16 B.C. By way of comparison, Tibullus is thought to have published the first book of his elegies not long after 27 B.C., the presumed date of the triumph by Messalla celebrated in 1.7; the year 25 B.C. is a likely date. However, Peter E. Knox has recently argued that 1.7 better suits the year 29 B.C., and if publication of Book I followed soon after, then the usually assumed priority of Propertius in regard to Tibullus would have to be reversed ${ }^{2}$. The date of publication of the second book is not known, but since Tibullus probably died in 19 B.C. ${ }^{3}$, it will have preceded Horace's fourth book by several years. Ovid too may have been producing poetry around this time: J.C. McKeown has argued that the earliest version of the Amores might have been performed in the mid-20s B.C., and published initially in 22 or 21 B.C., with the second edition, now reduced from five books to three, appearing sometime between 12 and 7 B.C. . Thus, when Horace was composing his amatory poetry, which represents numerically something over a fifth of the total number of odes, a fairly well-defined body of love poetry, sufficiently coherent, despite internal differences, to deserve the name of genre, was in circulation, and could serve as a point of contrast with Horace's lyrics 5 .

It is sometimes overlooked, however, that there was also another corpus of erotic poetry circulating in Rome at this time, namely epigrams, written chiefly, it would appear, in Greek but sometimes by writers who were fluent in Latin or

${ }^{1}$ This paper began as a joint contribution by myself and Regina Höschele, and much of the argument concerning Marcus Argentarius derives from a study that she and I have been preparing together. It is presented here with her kind permission, and in turn I dedicate this essay to Regina. 16.

${ }^{2}$ Peter E. Knox, "Milestones in the Career of Tibullus", Classical Quarterly 55 (2005) 204-

${ }^{3}$ However, a date as late as 16 has been suggested: for arguments, see Harry C. Schnur, “When Did Tibullus Die?", Classical Journal 56 (1961) 227-229.

${ }^{4}$ J.C. McKeown, ed., Ovid: Amores, vol. 1 (Liverpool: Francis Cairns, 1987).

${ }^{5}$ See the contribution by Paolo Fedeli in this volume, who notes how the young Horace "aveva contrapposto alle loro [sc. the elegiac poets'] patetiche effusioni sentimentali un atteggiamento di serena compostezza e d'imperturbabilità nei confronti dei contrasti d'amore”. 
indeed native speakers. These epigrams may have made the rounds individually, whether in single sheets or in recitations, or they may have appeared in authorial collections, like elegy and like Horace's Odes, although we know of them mainly through their anthologization in the Garland of Philip. The earliest poet to be included in this latter collection is Philodemus, while the latest is datable to some time before the death of Caligula; thus the range is between 90 B.C. and A.D. $40^{6}$. One of the best and most interesting poets in this Garland is Marcus Argentarius. Now, the elder Seneca mentions an Argentarius in his Controversiae, and at 9.3.12-13 informs us that, even though he was Greek, "he would never declaim in Greek, and he was always amazed at those who, not content with eloquence in one language only, after they had declaimed in Latin, would take off their toga, put on a Greek cloak, and, returning like an actor who had changed his mask, declaim in Greek". Since the name Argentarius is very rare $^{7}$, it is plausible that this bilingual Greek who insisted on orating in Latin is the same as the epigrammatist, in which case one may date his floruit with some confidence to the period between 20 B.C. and A.D. 16., that is, more or less contemporary with the time at which elegy, and Horace's Odes, were being published. Of the 50 or so surviving epigrams ascribed to Marcus, fully half are amatory in nature; thus, they provide a good sample against which to compare both elegy and Horatian love lyric.

Many have observed that Horace addresses his love poems to a series of girls or women, in contrast to the elegiac poets, who single out one object of their amorous desire and trace the course of the affair from its beginnings to the moment of dissolution, when the poet is at last free of the passion that has motivated his verses. One recent translator of Horace remarks: "Although he represents himself as devoted to love, it would be pointless to seek among his Lalages, Neaeras, Lydias, Lydes, and Leuconoes even the shadow of a Lesbia", taking Catullus' enamorment as the model for an authentically passionate romance ${ }^{8}$. Yet such a range of amorous addressees, complete with Greek names, is the stuff of epigram. Meleager, writing nearly a century earlier, provides a good array, but so too does Marcus Argentarius, who mentions an Ariste, Melissa, Antigone, Pyrrha (a name found also in Horace), Alcippe, Isias, Euphrante, Menophila, Lycidice, Dioclea, and Heraclea. What is more, some of the themes that are favorites with Horace recur in the epigrams. Take, for example, Odes 1.25:

\section{Parcius iunctas quatiunt fenestras iactibus crebris iuvenes protervi nec tibi somnos adimunt amatque ianua limen,}

${ }^{6}$ For details, see A.S.F. Gow and D.L. Page, eds., The Greek Anthology. The Garland of Philip and Some Contemporary Epigrams, 2 vols. (Cambridge: Cambridge University Press, 1968), introduction. But see Alan Cameron, The Greek Anthology from Meleager to Planudes (Oxford: Oxford University Press, 1993) 56-65, who dates Philip's Garland to the Neronian era.

${ }^{7}$ See Gow and Page (above, n. 6) vol. 2, p. 166.

${ }^{8}$ Rubén Bonifaz Nuño, trans., Horacio: Epodos, Odas y Carmen Secular (Mexico City: Universidad Nacional Autónoma de México, 2007) viii. 


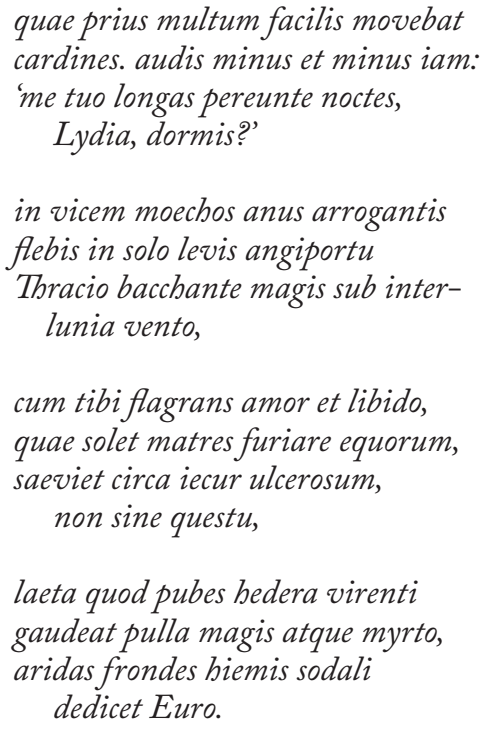

Ronnie Ancona, one of the few scholars to treat Horace specifically as a love poet, reads this ode as illustrating "the dominance of the theme of temporality in the particular love situation", in line with her view that time is central to Horace's conception of love'. But however ingenious Horace's treatment of it, the topos is not altogether a novel one. Compare Marcus Argentarius $(A P 5.118=11$ Gow-Page $)$ :

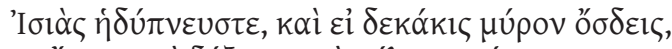

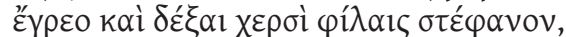

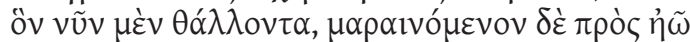

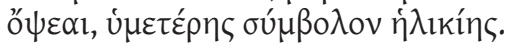

Sweet-breathing Isias, though you smell of perfume ten times over, rouse yourself and take this garland in your dear hands; just now it is blooming, but towards dawn you will see it fading, a symbol of your youth (trans. Gow-Page).

Horace's poem is far more aggressive than Marcus's - it is reminiscent of the more violent of his epodes - and, of course, it is far more elaborate than Marcus's brief four-liner. Marcus addresses a still young courtesan, whom he asks to wake up (egreo) and prepare for action. The comparison with a wreath softens the threat of aging, and at the same time suggests the trade of the courtesan, who, despite the perfume she already wears to excess, must still adorn herself for her client. What is more, she is evidently expected to entertain him until morning - it is plausible that she is being awakened late in the day, in accord with her professional time table, by which she sleeps during

${ }^{9}$ Ronnie Ancona, Time and the Erotic in Horace's Odes (Durham NC: Duke University Press, 1994) 22. 
daylight and works through the night. Horace directs his poem to a woman who is already aging (cf. parcius, minus et minus iam), and his description of her future desolation is brutally direct. His ode lacks the genial good humor of Marcus' epigram, with its suggestion of familiar banter among hetaerae and their clients; Horace rather adopts the resentful pose of a lover who has been rejected, and now imagines, in his desire for revenge, a hideous old age for a woman already past her prime.

If Horace 1.25 is about an attractive woman grown old, 1.23 is about a girl who is too young, or pretends to be:

\author{
Vitas inuleo me similis, Chloe, \\ quaerenti pavidam montibus aviis \\ matrem non sine vano \\ aurarum et siluae metu.
nam seu mobilibus veris inhorruit adventus foliis seu virides rubum dimovere lacertae, et corde et genibus tremit.

atqui non ego te tigris ut aspera Gaetulusve leo frangere persequor: tandem desine matrem tempestiva sequi viro.

Now, Marcus too has a poem about a girl who is still attached to, or at least under the supervision of, a mother $(A P 5.127=12 \mathrm{G}-\mathrm{P})$ :

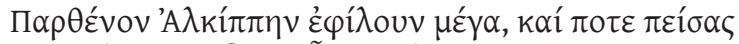

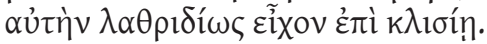

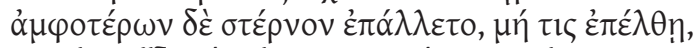

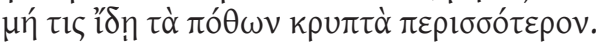

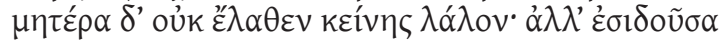

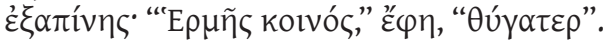

I was much in love with a maiden, Alcippê, and one day I prevailed on her and held her secretly on her bed. Both hearts were beating, lest anyone come near, lest anyone see the secrets of our surpassing passion. But her mother noticed [...] and looked in suddenly and said, «Hermes in common, my daughter» (trans. Gow-Page, modified).

As Gow and Page explain, «the finder of things lost was expected to go shares with any witness of his luck, and Hermes was the god who brought good luck». "Hermes», then, stands in here for hermaion. In one of the rare articles dedicated to Marcus Argentarius, Michael Hendry, however, has pointed out that the Hermes of the herms was typically equipped with an erect phallus, and that the joke here is double, the reference being both to 
something shared and something bared ${ }^{10}$. For all the wit, however, there is something shocking in the poet's claim to have seduced a young virgin, who is bold enough to consent to the affair but still terrified, like the poet himself, that someone may intrude upon them in the act of love-making - and that it should be her mother who does so - and who demands a piece of the action, no less - makes it among the raciest poems in classical literature. But in fact, Alcippe is not a modest maiden swept off her feet by a sophisticated lover, but a novice hetaera; and if the reader did not realize this from the beginning, then Marcus gives it away in the final distich, precisely with the word "mother".

Who is this "mother"? In Roman elegy, which was, as we have seen, more or less contemporary with Marcus' epigrams, the poet typically represents himself as an independent adult, that is, not in patria potestate: in this, he is like Marcus and other writers of lyric and epigrammatic verse. Nowhere is there mention of a father as an obstacle to the poet's affair, as is so often the case in New Comedy. Propertius indicates that his mother and father are dead (2.20.15), and in a passage that recalls Andromache's words to Hector in Iliad 6 describes Cynthia as constituting his parents and whole household ( $t u$ mibi sola domus, tu Cynthia sola parentes, 1.11.23); Tibullus, in turn, imagines his mother and sister, but no male relatives, weeping at his funeral (1.3.58). Correspondingly, neither is the elegiac mistress under the control of a male guardian. Cynthia has neither brother nor son (Propertius 2.18c.3334), although Propertius does mention her mother and sister (2.6.11-12; cf. 2.3.26, 2.15.20). So too, Tibullus speaks of Delia's mother (1.6.57-58) and of Nemesis' deceased sister (2.6.29), and Lygdamus imagines Neaera's mother weeping over the death of her son-in-law (Corpus Tibullianum 3.2.13-14). The presence of a mother does not conjure up the image of familial propriety that a father would ${ }^{11}$.

In this, elegy would seem to resemble New Comedy, in which a young courtesan is frequently under the protection of a mother or foster-mother (or mother-figure), for example in Plautus' Cistellaria (2, 38, 46, 83, etc.) and Miles Gloriosus (100-12, 975-76), as well as in Terence's Self-Tormentor (269-70) and Phormio (96-98). The formula is evident also in Menander: in the Periciromene, Glycera, the concubine of the soldier Polemo, has been raised by a foster-mother, who rescued her and her brother when they were exposed by their father (cf. also Alciphron 2.24.1, and contrast Alciphron 1.6.1, of a well-bred girl who notes emphatically that she is the daughter of a respectable father and mother). The pattern is general enough that when, in an erotic context, there is mention of a girl's mother but no father or male kúpros, one can assume that she is not of a respectable family, a point

\footnotetext{
${ }^{10}$ Michael Hendry, “A Hermetic Pun in Marcus Argentarius XII GP (A.P. 5.127)”, Hermes (1991) 119497.

${ }^{11}$ For fuller discussion of the absence of the paternal lineage in reference to the elegiac mistress and her poet-lover, see David Konstan, Sexual Symmetry: Love in the Ancient Novel and Related Genres (Princeton: Princeton University Press, 1994).
} 
that sheds light, incidentally, on the ribald scene at the end of Aristophanes' Ecclesiazusae, in which a girl vies with three old women for the sexual favors of a young man, in a way that would have been inconceivable in a well-bred citizen maiden. Aristophanes has provided a clue to the girl's station in a way not unlike Marcus' epigram. The girl sings:

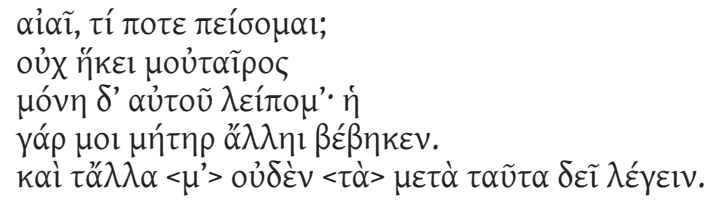

Ayyy, what will happen to me? My boyfriend has not come and yet I am left here alone: for my mother has gone out. No need for me to say any more.

The reference to a mother, but no father, was a tip-off to the audience of the kind of girl she is ${ }^{12}$.

But if the girl in Marcus' epigram is a budding hetaera, why is she so shy about sex, and what is the harm in her mother finding out about it? One can hazard an answer, again in line with the topos of the young hetaera. This may well be Alcippe's first sexual experience: she is called a parthenos, after all. According to the stereotype of Plautus' Cistellaria or Ovid Amores 1.8, the mother will not want her daughter to bestow her favors freely on a man just because she is in love: the mother will have had a better sense of commerce than that - particularly, perhaps, in the case of a girl who may still be a virgin. This is not a situation in which a proper mother walks in on an errant daughter, as in Achilles Tatius' novel, Leucippe and Clitopho (2.23.5-6), for example, and responds with bourgeois dismay at her seduction. The mother in Marcus' epigram, we may imagine, sees her daughter's behavior as bad business, and the girl knows it. But, being who she is, Alcippe's mother makes the best of it, and demands a share of the windfall.

Here we see, then, a substantial difference between the spirit of Marcus' erotic world and that of elegy. The elegiac mistress may be free of paternal control, but she is not quite the professional courtesan that Marcus tends to patronize: it is impossible to imagine a Cynthia or a Delia in bed in her mother's home, and prepared to share the poet's favors into the bargain. It is enough to think of the aurea anus or "golden old lady" of Tibullus 1.6.58, or the woman in 1.3.83-90, where Tibullus conjures up a scene of Delia chastely weaving in the company of an old lady (cf. Terence's description of the faithful Antiphila at Self-Tormentor 274-95).

How, then, are we to imagine the situation of Chloe in Horace 1.23, who avoids him like a fawn seeking its mother, and whom he urges to leave her

${ }^{12}$ On this passage in Aristophanes, cf. Stephen Halliwell, "Aristophanic Sex: The Erotics of Shamelessness", in Martha Nussbaum Juha Sihvola, eds., The Sleep of Reason (Chicago: University of Chicago Press, 2002) 133. 
mother, now that she is of an age to suited rather to a man, or perhaps a husband (vir)? Are we to suppose that she has a father, and is thus a proper citizen daughter, being courted for marriage? This is unlikely, I think, given what I take to be a convention concerning mentions of a girl's mother but not a father. Yet Horace suggests nothing so crude as Marcus' set-up, in which mother and daughter alike are evidently courtesans, even if the daughter, Alcippe, is only beginning on her career. Is Horace's Chloe then more like the elegiac mistress, with her mother in the background? Not this either, I am inclined to believe: the women in Propertius, Tibullus, and Ovid are grown up and independent, and make their own arrangements: no one has to advise them to separate themselves from their mothers. Horace has created a different scenario from either the elegiac or the epigrammatic, in which the girl seems to be of a status somewhere between that of a hetaera and of a marriageable virgin. But it is precisely by situating his ode against the backdrop of both these genres, and the way they exploit a topos that in its general outline is similar in all three, that we can best appreciate Horace's originality in respect to his amatory persona.

Horace Odes 1.30 is clearly based on a Greek epigram, this time by a much earlier poet, Posidippus $(A P 12.131)^{13}$ :

\author{
O Venus regina Cnidi Paphique, \\ sperne dilectam Cypron et vocantis \\ ture te multo Glycerae decoram \\ transfer in aedem. \\ fervidus tecum puer et solutis \\ Gratiae zonis properentque Nymphae \\ et parum comis sine te Iuventas \\ Mercuriusque.
}

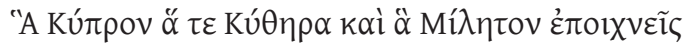

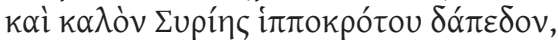

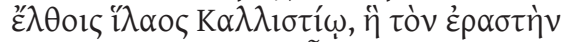

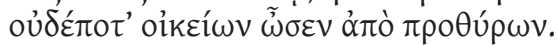

The Greek poet summons Aphrodite from her usual cultic habitats so that she may visit the hetaera Callistion, who deserves the goddess's attention because she never drives any lover from her door. So too, Horace calls upon Venus to abandon her favorite haunts and to take up residence in the aedes of Glycera, who has been calling upon her along with rich offerings of incense. Horace's summons is more imperious: he begs Venus to disdain (spernere) the places that she loves (dilectam); in an erotic context, the word suggests repelling lovers - just what Callistion is rewarded for not doing. What is more, Horace

${ }^{13}$ For the allusion to Posidippus, see R.G.M. Nisbet and M. Hubbard, eds., A Commentary on Horace Odes, vol. 1 (Oxford: Oxford University Press, 1970) 344 (the connection was originally identified by Richard Reitzenstein). 
pretends to be speaking in support of Glycera's own appeal to Venus, whereas Posidippus invokes Aphrodite on his own, evidently in gratitude to Callistion, and as a favor to her - he prays that Aphrodite will be propitious (bilaos); at the same time, Aphrodite's coming is a symbol of Callistion's selfless devotion to the goddess of love.

Horace gives no such explanation of the reason for his summons: he is, as we have seen, simply supporting Glycera's own wish, the reason for which is not specified: she may be frustrated in love, for example: the model of Sappho fragment 1 comes immediately to mind. If this is the case, and Glycera's apparent urgency in invoking the goddess may suggest something of the sort, then Glycera is not necessarily to be imagined as a hetaera, like Callistion: she may be, of course, but then again, she may be of the status of the elegiac mistress, and herself in love, conceivably even with the poet's own persona, or else with another - here again, the situation is ambiguous. Finally, and most puzzling, why does Horace ask that Cupid, the Graces, the Nymphs, Youth, and Mercury accompany Venus? He seems to be inviting quite a crowd to Glycera's house or chapel. Cupid, the Graces (especially with their belts undone), and the Nymphs are perhaps natural enough companions for the goddess of love. That Youth is not pleasant apart from Venus perhaps contains the hint of a warning to the girl - make love while you still have your good looks - though she seems eager enough to propitiate Venus on her own: unless perhaps we are to infer that she is not so young, and that is why the poet wishes that Youth too visit her. Finally, Mercury is conceivably being invoked in connection with his role as patron of commerce ${ }^{14}$; if this is so, then there may be a hint of a professional capacity on the part of Glycera, though why the poet should make this plea in her behalf is not entirely clear.

In all this, one point about Horace's ode, in contradistinction to Posidippus' epigram, seems reasonably clear: whereas Posidippus is personally moved by Callistion's generosity toward her lovers and invokes Venus out of gratitude or good will, Horace presents himself rather as seconding Glycera's wish, like a benevolent outsider. He may be an interested party, but the reader cannot be sure: he may just as well be assuming the role of a wise counsellor. If so, it is a posture that characterizes Horace's amatory persona in a number of his lyrics, and it is just this that separates his voice both from the epigrammatic erotic tradition and the elegiac.

In order to indicate how Horace establishes his characteristic persona in his love poems, I propose to examine the sequence of the first few odes in Book

${ }^{14}$ This is the view of Kenneth Quinn, ed., Horace: The Odes (New York: St. Martin's Press, 1980) 131, who writes of Glycera: "she is no victim of unrequited love, but a demi-mondaine whose business is booming”. David A. Traill, "Horace Carmen 1.30: Glycera's Problem,” Classical Philology 88 (1993) 332, suggests that Glycera may rather be an aging hetaera, as suggested both by the urgency of her appeal to Venus and the poet's own mention of Iuventas. R.O.A.M. Lyne, "Horace Odes Book 1 and the Alexandrian Edition of Alcaeus", The Classical Quarterly 55 (2005) 542-58, noting the location of 1.30 between two more serious political poems, connects Mercury here with the Augustan god celebrated in Ode 1.2, just as the mention of the Nymphs may allude to poem 1.3 (p. 555). 
1 , detached from their context in the book as a whole. I do not mean to suggest that the location of the amatory odes in the entire series of poems is without art or importance, and indeed I have already hinted at some possible associations with the collection as a whole. Nevertheless, and curiously enough, it seems that no one has so far considered the order of the erotic odes on their own, and how their arrangement may contribute to the poet's self-representation. As will emerge, the way the odes develop also sheds light on their position between elegy and epigram.

Odes 1.5 is the first of the amatory poems in the collection, and it at once announces some of the main themes that will mark Horace's approach to love:

Quis multa gracilis te puer in rosa

perfusus liquidis urget odoribus

grato, Pyrrha, sub antro?

cui flavam religas comam

simplex munditiis? heu quotiens fidem

mutatosque deos flebit et aspera

nigris aequora ventis

emirabitur insolens,

qui nunc te fruitur credulus aurea, qui semper vacuam, semper amabilem

sperat, nescius aurae

fallacis. miseri, quibus

intemptata nites: me tabula sacer

votiva paries indicat uvida

suspendisse potenti

vestimenta maris deo.

The final verses, in which Horace explains that he has retired from love's battles and made a votive offering of his gear, ties the poem to the epigrammatic tradition of dedicatory inscriptions ${ }^{15}$. As to the girl's name, one might speculate that Horace has begun with Pyrrha because she bears the name of the primordial woman, the only one to survive the original flood, whom Horace had already mentioned in 1.2: here, she is the first to take the stage in an erotic context ${ }^{16}$. Again, the love theme is prepared by 1.4, which celebrates spring time, ushered in by Venus, Nymphs, and the Graces ${ }^{17}$. Horace has also brought together past, present and future in this brief ode, as he describes Pyrrha's current affair, predicts that the boy who now enjoys her favor will soon weep, and recalls his own earlier decision to withdraw from the game, so that he is now immune to

\footnotetext{
${ }^{15}$ For a detailed discussion of this poem in relation to Greek epigram, see the contribution by Regina Höschele in this volume.

${ }^{16}$ I owe this suggestion to Regina Höschele.

${ }^{17}$ These deities perhaps anticipate also the grouping in Odes 1.30 .
} 
the danger of fickle Pyrrhas, even as he intimates his own former vulnerability and repeated disappointments. What is most striking, however, is that Horace launches his sequence of amatory lyrics by assuming the posture of an older, wiser advisor, a preceptor amoris, one who stands outside or above the fray. He speaks to Pyrrha - it is she whom he knows, not the hapless boy she has seduced - and he knows what to expect of her. However, he does not speak of his own passion or distress, but projects, from a position of disillusionment, his prior frustrations onto the unidentified youth. This sets the tone, and defines Horace's persona, for many of the odes that follow: a world-weary, half-nostalgic recollection of love's tumultuous passions. One is reminded of William Wordsworth's dictum, in his Preface to Lyrical Ballads, that "poetry is the spontaneous overflow of powerful feelings: it takes its origin from emotion recollected in tranquillity". The emotions seem to be lurking beneath the surface of the poem, but are displaced onto another, while Horace maintains his distance.

The next erotic poem in the sequence is Odes 1.8:

\author{
Lydia, dic, per omnis \\ te deos oro, Sybarin cur properes amando

Here again, Horace addresses a woman who has so charmed a young man as to distract him from virile pursuits and leave him pale and enervated. The emphasis is on the immediate effects of enamorment rather than, as in 1.5, the false hopes that will be dashed when the fickle girl turns her attentions elsewhere. The comparison with Achilles alludes to the attempt of his mother, Thetis, to disguise him as a girl on the island of Scyrus, so that he would not 
be drafted into the war at Troy which from battle in the Iliad ${ }^{18}$. The connection with Troy is perhaps further indicated by the use of flavus, "yellow", applied to the Tiber, alluding to the name of Troy's river, Xanthus (xanthus = "yellow") ${ }^{19}$. There is thus an identification between the athletic activities on the Campus Martius, which Horace probably had in mind as the locale where Sybaris should be engaging in military games and sport, and the battlefield round Ilium ${ }^{20}$. In this ode, unlike 1.5 , Horace's persona reveals nothing of his own situation, save that he evidently looks askance at Sybaris' unmanly surrender to Lydia's attractions (Lydia, like Sybaris, was conventionally associated with unwarlike effeminacy). He thus assumes the voice of civic and martial duty as opposed to romance, and we may assume that he is not, at the moment, himself under the sway of a strong erotic passion, although he clearly is aware of its effects ${ }^{21}$. Besides, it is not some anonymous "skinny kid" (gracilis puer) that he imagines, but a young man he knows by name, and of whose normal activities he is well aware. If the poet is in a position to preach about duty, he may nevertheless be somewhat more involved in the young man's situation than he pretended to be in the previous ode.

In the next ode on an amatory subject (1.13), Horace, or his persona, is clearly more deeply engaged; indeed, it is plausible that his posture of sage counsellor in fact masks his own jealousy - a sentiment that Horace may well be the first poet in classical antiquity to express in all its romantic implications ${ }^{22}$ :

\author{
Cum tu, Lydia, Telephi \\ cervicem roseam, cerea Telephi \\ laudas bracchia, vae meum \\ fervens difficili bile tumet iecur.
}

${ }^{18}$ There is perhaps also a hint at Achilles' withdrawal from battle at Troy itself, which Horace may be reading, playfully, as motivated by his frustrated desire for Briseis (cf. Odes 2.4.2-4) rather than by Agamemnon's insult to his honor - the principal cause of his resentment in the epic.

${ }^{19}$ See David Konstan, "Introduction: Viewing Horace”, Arethusa 28 (1995) 141-49.

${ }^{20} \mathrm{On}$ the Campus Martius as the site referred to in this ode, see Mary Jaeger, "Reconstructing Rome: The Campus Martius and Horace, Ode 1.8”, Arethusa 28 (1995) 177-91. For the associatiion between the Campus Martius, the Tiber, and military activity see also Kenneth Quinn, Latin Explorations (London: Routledge and Paul, 1963) 137-41; Michael Dyson, “Horace, 'Odes' 1.8: The Love of Lydia and Thetis”, Greece E' Rome, 2nd Series, 35 (1988) 164171.

${ }^{21}$ Dyson (above, n. 20) suggests that the poem may be more sympathetic than it seems to Sybaris' negative attitude toward war, and notes that in at least one earlier version, Achilles agrees to hide out on Scyrus out of love for a girl (Bion 2.11-26). Eleanor Winsor Leach, "Horace Carmen 1.8: Achilles, the Campus Martius, and the Articulation of Gender Roles in Augustan Rome”, Classical Philology 89 (1994) 334-43, finds indications of an anti-Augustan posture in the poem, especially in connection with the idea of cross-dressing.

${ }^{22}$ For fuller discussion of jealousy in this ode, see David Konstan, The Emotions of the Ancient Greeks: Studies in Aristotle and Classical Literature (Toronto: University of Toronto Press, 2006) ch. 11 . 
tum nec mens mibi nec color

certa sede manet, umor et in genas

furtim labitur, arguens,

quam lentis penitus macerer ignibus.

uror, seu tibi candidos

turparunt umeros inmodicae mero

rixae, sive puer furens

inpressit memorem dente labris notam.

non, si me satis audias, speres perpetuum dulcia barbare

laedentem oscula, quae Venus

quinta parte sui nectaris imbuit.

\author{
felices ter et amplius \\ quos inrupta tenet copula nec malis \\ divolsus querimoniis \\ suprema citius solvet amor die.
}

Here again, Horace takes on the role of counsellor, but this time it is the woman, again named Lydia, who is in love: the poet listens or overhears her as she praises another man's charms. Lydia's evident infatuation with Telephus causes an intense physical reaction in the speaker. One may well imagine that Horace is or has been in love with Lydia. Indeed, although he does not explicitly affirm that he himself is more deserving to be Lydia's lover, his acute reaction to her passion for Telephus suggests that he perceives Telephus as a rival. If so, however, he seems to be proposing to Lydia a different kind of relationship: not the wild but inevitably short-term sensual affair that Telephus offers, but a more enduring love that lasts until death itself. The contrast recalls that in Catullus 109 between a iucundus amor, such as Lesbia intimates, and an aeternum sanctae foedus amicitiae. If Horace's persona here has outgrown the raw desire represented by Lydia's liaison with Telephus, and in this respect recalls the cool, detached speaker in 1.5 , he is nevertheless sufficiently drawn in to wish that he might supplant Telephus in Lydia's regard. The poet who in 1.8 presumed to offer counsel to a lovelorn character modelled on Achilles here proves barely up to competing with a Telephus, who had to come begging Achilles to heal him of the wound which that same Achilles had inflicted ${ }^{23}$.

Given the sequence of Horace's amatory odes so far, with the apparent crescendo in the poet's own engagement with the passions he describes, it comes as no surprise that in the next love poem (1.19) he should find himself

${ }^{23}$ The points made here are developed at greater length in David Konstan, "Before Jealousy," in David Konstan and N. Keith Rutter, eds., Envy, Spite and Jealousy: The Rivalrous Emotions in Classical Greece (Edinburgh: University of Edinburgh Press, 2003 = Leventis Studies vol. 2) 7-27, and "Die Entdeckung der Eifersucht", Antike und Abendland 51 (2005) 1-12. 
wholly surrendering to erotic impulses he had imagined he had escaped (finitis animum reddere amoribus):

Mater saeva Cupidinum Thebanaeque iubet me Semelae puer

et lasciva Licentia finitis animum reddere amoribus.

urit me Glycerae nitor splendentis Pario marmore purius, urit grata protervitas et voltus nimium lubricus adspici.

in me tota ruens Venus

Cyprum deseruit nec patitur Scythas

et versis animosum equis

Parthum dicere nec quae nibil attinent.

bic vivum mibi caespitem, hic verbenas, pueri, ponite turaque

bimi cum patera meri:

mactata veniet lenior hostia.

Glycera and Venus have won the day, and the poet who, in 1.5, thought he had given up the game for good is now again a victim of erôs. This is the same situation that Horace evokes in the first ode of Book 4 (vv. 1-12), underscored by the repetition of the verse mater saeva Cupidinum:

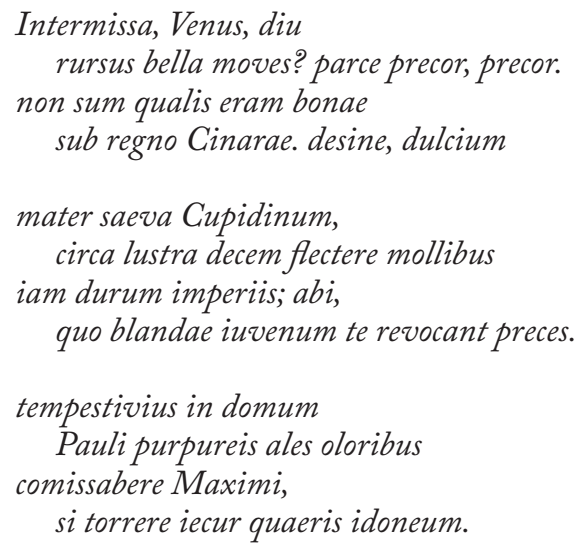

By Odes 1.19, Horace is already fully back in the game, no longer playing the detached adviser to young men (as in 1.5 and, indirectly, in 1.8) or a young woman (as in 1.13), but himself subject to Venus and in need of help. From now on he will speak like a man in love, or one who has clearly known its power, whether he 
softens the tone and humorously suggests that love confers a serene and indeed divine security, as in 1.22 (integer vitae), or, as in the first two poems discussed above $(1.23,1.25)$, he encourages a girl to leave her mother's side or else warns a woman experienced in the ways of passion of the gloom that old age will bring.

Such is the narrative trajectory suggested by the first seven amatory poems in Book I of Horace's Odes, if we read them as constituting an ordered sequence. Of course, the elegiac poets too presented their affairs as marking a progression from initial enamorment to final disillusionment and the dissolution of the romance; and it is possible that epigrammatists like Marcus Argentarius did so as well, though in the absence of adequate evidence for how they may have organized their book rolls (the case of the Milan Posidippus may not be representative of the practices of poets writing in the age of Augustus), it is impossible to be sure. Both the elegiac poets and Marcus Argentarius were capable of adopting, on occasion, the role of praeceptor amoris, in the sense of offering advice to lovestruck boys and girls. But Marcus' tone in such poems is markedly different from that of Horace. An example is AP $5.116=10$ Gow-Page):

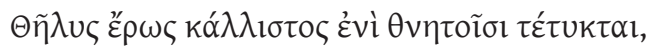

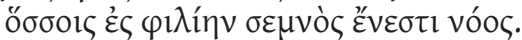

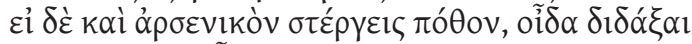

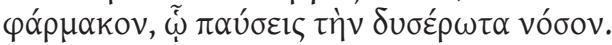

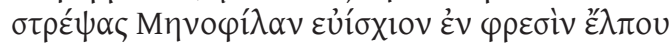

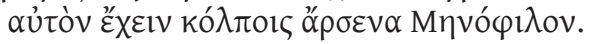

Woman's love is best for mortals, all who have a serious mind for love. If you cherish desire for males too, I can teach you a medicine by which to stop that sick-love malady: turn Menophila's skinny hips about, and in your mind imagine that you have a male Menophilus in your embrace (trans. Gow and Page, modified).

There is nothing here of the mock-righteous tone of Horace as he bewails Lydia's grip on Sybaris, thereby keeping him from manly pursuits. Marcus' epigram is clearly a joke, which is based in turn on a poem by Dioscurides ( $A P$ 5.54.5-6), in which he gives advice for sleeping with a pregnant woman: $\dot{\alpha} \lambda \lambda \dot{\alpha}$

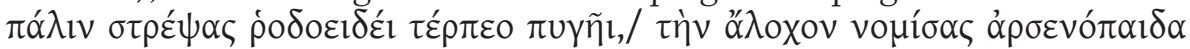
Kúmpıv. The idea may be that turning Menophila around will serve as a transitional strategy, like eating veggie burgers to break an addiction to meat; but however the procedure that Marcus proposes may be presumed to work, the point of the epigram is not a cure for homoerotic passion but a joke at Menophila's expense. Marcus' persona is that of a connoisseur of hetaeras, able to recommend the right girl for any taste, including a predilection for pederasty (he takes it for granted that Menophila is agreeable to being used in this way). He is at the opposite pole from the elegists, who are rather inclined to warn their friends off the kind of passion from which they themselves suffer so desperately; an example is Propertius 1.6 (I cite vv. 1-24): 
Non ego nunc Hadriae vereor mare noscere tecum,

Tulle, neque Aegaeo ducere vela salo,

cum quo Rhipaeos possim conscendere montes

ulteriusque domos vadere Memnonias;

sed me complexae remorantur verba puellae, mutatoque graves saepe colore preces.

illa mibi totis argutat noctibus ignes, et queritur nullos esse relicta deos;

illa meam mihi iam se denegat, illa minatur quae solet ingrato tristis amica viro.

his ego non horam possum durare querelis: ah pereat, si quis lentus amare potest!

an mibi sit tanti doctas cognoscere Athenas atque Asiae veteres cernere divitias, ut mibi deducta faciat convicia puppi Cynthia et insanis ora notet manibus, osculaque opposito dicat sibi debita vento, et nibil infido durius esse viro?

tu patrui meritas conare anteire secures, et vetera oblitis iura refer sociis.

nam tua non aetas umquam cessavit amori, semper at armatae cura fuit patriae;

et tibi non umquam nostros puer iste labores afferat et lacrimis omnia nota meis!

Horace does not offer counsel from within the throes of passion, as Propertius does, but affects to have overcome it, and then proceeds to illustrate how he is drawn back into the tide. Even then, it is not with one woman, but with a host of them: he is like Marcus and the epigrammatists in this, but without the often coarse humor of a hard-edged roué, at home in the demi-monde of professional courtesans. Horace would seem to have created an amatory persona of his own, seasoned but still susceptible to passion, maintaining a certain philosophical aloofness even as he watches himself yield to the power of Venus. In this sense, he can be said to stand midway between epigram and elegy. 